\title{
Strengthening Public Affairs through Project Financing of the Franchise Contract Foreign Intervention
}

\author{
Guo Xinyu ${ }^{1}$ \\ School of Public Management, Yunnan University of Economics and Finance, Kunming,P.R.China, 650221 \\ (gxy0871@163.com)
}

\begin{abstract}
To participate in the public service in a way of franchising by project financing and intervention of the public affairs is a special operation idea and ability to resist risks, providing a way for the marketization of public utilities in our intervention. Through franchising way of introducing foreign capital can not only reduce conflict attributing to the public management market intervention model in respective countries but also put this conflict into the integration of the legal system of the host country.
\end{abstract}

Key words: Public affairs; project financing, Foreign enterprise

\section{Introduction}

Because of the global financial crisis in 2008 , the world economy had witnessed decline in varying degrees, which will also hold economy in recession. Compared with other countries, Chinese government's coping with the international financial crisis has taken a series of macro-control measures in investment and consumption to develop our economy. Chinese economy is the first to recover. Therefore, compared with other developed countries, many countries around the world are inclined to invest in Chinese market.

\section{Summary}

In the field of public affairs, thanks to the reform and opening-up policy, China has been exploring a way on how to break the natural monopoly and administrative monopoly in public affairs in order to change the state-owned monopoly enterprise USES the public all, public finance and public management the government investment management mode of operation caused by the inefficient, the phenomenon such as long-term supply. Public service done by the government will no longer exist, but by introducing market competition mechanism to the private capital and foreign capital to develop financing, in the form of project financing of franchising introducing private capital, foreign capital, foreign technology and advanced management experience in related field. Instead of the investment management pattern of government, "the goal is not clear with the lack of management autonomy and responsibility system, financial distress and Labour problems... public enterprise or organization management become loose, and the desire of reducing cost is not strong" etc, vigorously promote foreign investment in the form of project financing of franchising enterprises to participate in our country's public utilities services, is not only a response to the new situation "push to provide diversity and provide ways of public service", but to deal with the development of infrastructure money supply tension and improve the efficiency of production and operation.

\section{Project financing mode of franchise contract summary}

Project finance franchise contract need specification, and also need to prevent risks. The author chose the word " summary ", because the research on project financing of the franchise contract is not a complete system, but some details which need to be paid attention to. 


\subsection{Carry out limited administration excellent benefit right concept}

The author thinks, whether it is private enterprises or foreign-funded enterprises, the key to its cooperation with the government management of public affairs is the public power restriction and private rights. In general, guaranteeing the realization of public interests is the exercise of the right to adequate administration excellent benefit right, but because the administration excellent benefit right is a kind of discretionary power, "as long as the effective restriction on the public power to exclude power holders were judged and the freedom to make the possibility of selection, there discretion." ${ }^{1}$ Therefore, if there is not the legal system of administrative discretion in the supervision and regulation, it is highly risky to be misused or abused. In the project financing the franchise contract, the administrative contract, must highlight the attention to non-state investors interests concept, in the general case of equality, tilt the balance to the non-state investors protection. By analyzing the content of the contract fully refined and regulated, based on contracts in the implementation process on the exercise of administrative prior rights to regulate and control, in order to procedural consensus to resolve the entity rights disputes.

\subsection{Emphasis on the protection of the basic} principle of reliance interest

Project financing franchise contract is an administrative contract, administrative contract to some extent can be understood as a privileged civil contract. Therefore, in order to ensure the interests of the contract, the other party must have a corresponding privilege control. So in the contract, in

K.e.Davis, DiseretionaryJustiee:APreliminaryInquiry , universityof1llinoisPress(1971)P.2 addition to the civil contract that "freedom, justice, honesty and credit" principle, "the protection of the reliance interest" principle can be stressed. "The protection of the reliance interest" principle is emphasized for the government to keep a promise inviolate, then people can arrange their own lives rather than making the chaos of social order. In the franchise contract of project financing, the government may damage the interests of the other party trust prior right of administrative situation, mainly because of some reason caused the government to modify or terminate the franchise contract.

If the administration excellent benefit right is not due to the administrative relative person's fault, as in the changed circumstances making the contract based shake or loss. If we continue to perform the contract, it may damage the public interests, the government to exercise the right to rescind the contract or the right to change caused a loss of non state-owned investors interest shall be deemed to be trusted interests, whether government damage to the interests of the trust whether has the mistake, all should be compensation or compensation timely, adequate, reasonable. $^{2}$

\subsection{Note that the pricing method concession projects}

Project financing franchise should have two processes of changing pricing. The first is the change of the franchisee that has the right to operate the project right from the government; the second is a franchisee that will operate the expiration of the project transfer of management rights to the

${ }^{2}$ Chen Lin: "legal control" on the BOT Franchise Administration excellent benefit right in the agreement "," Master Thesis of Minzu University of China, 2010 
government or other investors. In order to maximize their interests, the project will be both prior to the transfer of assets evaluation, and then both parties will base changing pricing on evaluation. Because the decrease of evaluation value will result in the loss of state-owned assets, and the increase of assessment value may affect the enthusiasm of private investors. To some extent, evaluation of project financing mode of public project, in fact, is to assess the franchise value. As the franchise use intangible assets assessment, at present, generally with the replacement cost method and income current value $\operatorname{method}^{3}$ two assessment methods.

\subsection{Stable connection non state investors and item} company

In the management of Public Utilities Franchise in project financing, often-non-state investors participate in the bidding in project site and set up Item Company, then the item company become a franchisee franchise project. So, the concessionaire party appeared in two subjects, namely non-state investors and Item Company, between non stateowned investors and item company is one of the relationship between the shareholders and the company.

However, because the non-state investors in Public Utilities Franchise Bidding Project Financing item company has not established, the non state-owned investors bidding projects and government signed a franchise agreement, and the item company does not exist, but in the item company was founded to Title

${ }^{3}$ Chinese CPA Association: "the 2011 unified national examination for certified public accountants coachs teaching material", Beijing: Chinese political and Economic Publishing House, 2011 first edition in March, nineteenth pages; franchise agreement is signed by the shareholders need to consider and arrange. The author thinks, in the non-state investors in the successful bid, first signed a "strategic cooperation agreement" with the government, with agreement to be signed with the government item company was established after the "franchise agreement".

\subsection{Avoid item company control transfer, pledge}

According to the "eighteenth way" municipal public utility franchise management stipulates: "the enterprise that has obtained the franchise right of any of the following acts in the franchise period, the competent department shall lawfully terminated the franchise agreement, cancel its franchise, and can implement temporary regulation": (a) the unauthorized transfer, rental franchise; (b) to the operation of the property disposition or mortgage." Item company equity transfer is a kind of active without government approval would transform franchisee behavior, and unauthorized mortgage item company ownership is a kind of passive had not been approved by the government to transform franchisee behavior. Therefore, the government should decide agreed right transfer, pledge to franchisees scrutiny in the management of public utilities project financing the franchise contract, and shall be embodied in the requirements of articles of association. Of course, the equity pledge or transfer limit is also not overcorrect, as long as the original franchise operators can ensure the control status of the item company, part of the equity transfer or pledge financing behavior is not should be banned. These requirements and constraints must be refined in the franchise contract.

\subsection{To prevent the risk of government franchising}

Although the government is in a strong position to the abuse of administrative power, to prevent, alert. But in normal circumstances, the government will 
meet the public demand for public goods and services, the requirements in terms of management of Public Utilities Franchise on the performance of project financing for the government to ensure that the market access of the franchisee compliance, operation safety, guaranteed product quality and price setting.

First, in the contract management of public project financing in franchise (hereinafter called contract franchise), to clear the franchise is through open market, fair, notarization selected non state-owned investors, but also the non state investors in accordance with operating public service project financing franchise bidding conditions. At the same time, to clear the non state-owned investors exit conditions and specific requirements in the contract in franchise, restrict, promote non-state-owned Investors Service and efficiency.

In second, the contract should be clear in franchise, franchise operators in the item company was founded to establish and perfect the production rules, safety accident emergency plan, in addition to prepare or approval to the government administrative organ, but also regularly to the government administrative departments reporting production safety, product quality inspection accept the government administrative agencies, production safety and quality supervision and inspection and regular announced.

Third, in the contract in franchise, agreed to clear a franchisee shall regularly report to the government operating costs, operating income and other financial information, to reduce the price supervision department of information asymmetry.

3.7 Adhere to the mid-term evaluation of great significance

The "measures" municipal public utility franchise management provisions of article twenty-first: "during the operation of the project, the competent department shall organize experts to conduct midterm evaluation to obtain business franchise. The evaluation period shall not be less than two years, special circumstances can be the implementation of the annual assessment."

The author thinks, management of public utilities project financing franchise contract period, if the government and lax regulation, may be harmful to the public interest. The mid-term evaluation is an effective way of supervision for the long-term contract, in the course of the franchise, the government organized relevant experts assessment mission, the franchisee is in accordance with the "franchise contract" agreed to fulfill the corresponding obligations judgement, this is to safeguard the public interests, also assets on public utilities maintenance. The mid-term evaluation can supervise, improve, perfect management behavior of franchisees, improve its operating efficiency; even non state investors serious deviation from the "franchise contract" is true, the government can regain franchise according to assessment missions, lift the "franchise contract", re select the franchisee.

Therefore, we should set out the mid-term evaluation requirements in the management of public utilities project financing the franchise contract, evaluation contents shall include but not limited to the following several points: (1) business franchise operators to "target and requirement of the franchise contract"; (2) business franchise operators to "the provisions of the franchise contract" standards of operation; (3) business franchisees and full respect for the social and public interests.

\subsection{Reasonable pay franchise expires debt}

Although the management of public utilities project financing mode, the government has not clearly 
defined franchise expires project assets shall be paid or unpaid by the way, at present still rely on the franchise contract. But after the franchising period project assets paid transfer case, because the debt to asset reduction in the assessment of buybacks, debt clearance without limited too much, just to the franchising period of item company equity or assets during the period of time before the mortgage, pledge to restrictions can be. In the asset transferred franchise expires under item company ownership or project, project assets must be clear of all debts, so in the contract in franchise to be agreed on the following questions:

First, the franchising period of 1 2 years, item company debt rate index should have a standard, such as no more than $30 \%$ (or 20\%), and decreased year by year, so as to clear a debt total control; and in the franchise before the expiry of 1 years, item company have to clear the debt, in order to ensure the debt in the franchising period can be effectively controlled.

Second, in addition to the business before the expiration of the term debt rate shall be stipulated in the contract the franchise contract, also empowers the government to give special supervision of the franchisee debt agreement; at the same time, contracts may be stipulated in the franchise franchisee to pay off before the expiration of margin debt certain, in failing to pay off the debt, the government will have the right to confiscate the deposit to pay debts.

\subsection{Clear contract dispute belongs to the scope of} administrative litigation

In the contract management of public project financing in franchise, "such as the execution of this contract shall be stipulated in the process, the two parties of the contract disputes, non state investors that their rights are being infringed, it may bring an administrative lawsuit."

Because of project financing franchise contract has the administrative attribute distinct, so that the contract itself is not only the two parties of the contract a desirable outcome, more is a kind of administrative means for the government to achieve its social public interest duty. So the author thinks that in the project financing mode in the practice of administrative licensing, the administrative organ's breach of contract should actually be considered as a violation of the obligations in administrative law, is an illegal administrative act. But, in practice, administrative abuse of power and the default behavior often intertwined, therefore, in order to protect the legitimate rights and interests of non-state investors, the administrative procedure law of civil procedure law rather than more in line with the franchise contract judicial remedies. Notable is, the current "administrative procedure law" stipulated by the administrative body responsible for the allocation of the burden of proof is very consistent with the project financing characteristics of franchising, this also from another side that the project financing franchising litigation should apply the "administrative procedure law", the burden of proof will be more conducive to the protection non state owned the legitimate rights and interests of investors.

\section{Conclusion}

A perfect project financing franchise contract needs the government, the non-state investors, item company and other subjects of legal relation to franchising in close cooperation, and improve the existing system of laws and regulations related to the project financing of the franchise, this paper only from the angle of legal practice and expounds how to 
details in the project financing of franchise contracts in the attention and clear. In fact, legal support system project financing mode and how to establish a system and how to clear the project financing franchise various legal relationship of rights and obligations relationship should be a focus of future research work.

\section{Reference}

[1]Wang Songjiang. Research on [1] GMS national objectives oriented project planning based on P6. (First Edition). Yunnan: Yunnan Publishing Group / Yunnan science and Technology Press, 2009.11

[2] Zhang Dong. Franchising legal practice. (First Edition). Beijing: Law Press, 2008.12

[3] Wang Liming. The study of Contract Law (Volume I). (First Edition). Beijing: Renmin University of China press, 2002.11

[4] Wang Liming. Study on Contract Law (second volumes). (First Edition). Beijing: Renmin University of China press, 2003.6

[5] "people's Republic of China Contract Law" (2006

Edition). Beijing: China Legal Publishing House

[6] Robert K. Wysocki, Robert Beck Jr, David B.

Crane. Effective Project Management $\left(2^{\text {nd }}\right.$

Edition) . UK : John Wiley \& Sons, 2000.

[7]Statutory Instrument 2000 No.2009 Public Procurement-The Public Contracts (Works, Services and Supply) (Amendment) Regulations, 2000. 